\title{
Aspek biopsikososial ibu hamil bersalin dan nifas terkonfirmasi Covid-19: Rapid review
}

\author{
Silvia Rizki Syah Putri ${ }^{1}$, Cesa Septiana Pratiwi ${ }^{2}$, Herlin Fitriani Kurniawati ${ }^{3}$, Luluk Rosida ${ }^{4}$
}

1,2,3,4Universitas Aisyiyah, Yogyakarta

\section{INFORMASI ARTIKEL:}

\section{Riwayat Artikel:}

Tanggal diterima: 25 Mei 2021

Tanggal direvisi: 26 Juli 2021

Tanggal dipublikasi: 22 Agustus 2021

\section{Kata Kunci:}

Hamil

Bersalin

Nifas

Covid-19

\subsection{6/jrki.v5i1.163}

Keyword:

Pregnancy

Delivery

Postpartum

Covid-19

\section{ABSTRAK}

World Health Organization (WHO) menyebut coronavirus disease yang ditemukan pertama kali di Wuhan dengan novel coronavirus 2019 (2019$\mathrm{nCoV}$ ) yang disebabkan oleh virus Severe Acute Respiratory Syndrome Coronavirus-2 (SARS-CoV-2). Ibu hamil, bersalin, nifas dan bayi baru lahir juga merupakan sasaran yang rentan terhadap infeksi Covid-19 (Kemenkes RI, 2020). Tujuan dari Rapid Review ini adalah untuk mengetahui ibu hamil, bersalin dan nifas yang terkonfirmasi Covid-19. Dari 12 Artikel yang didapatkan ibu hamil, bersalin dan nifas terkonfirmasi Covid-19 dilihat dari aspek biologi, aspek psikologi dan aspek sosial. Tetapi masih diperlukan untuk mengivestigasi mendalam terkait pengalaman ibu hamil, bersalin dan nifas terkonfirmasi Covid-19.

The World Health Organization (WHO) calls the coronavirus disease that was first discovered in Wuhan with the 2019 novel coronavirus (2019-nCoV) caused by the Severe Acute Respiratory Syndrome Coronavirus-2 (SARS-CoV2) virus. Pregnant women, delivery women, postpartum women, and newborns are also vulnerable targets for Covid-19 infection (Kemenkes RI, 2020). The Rapid Review has the purpose of finding out pregnant, delivery, and postpartum women who are confirmed Covid-19. The 12 articles obtained by pregnant, delivery, and postpartum women confirmed by Covid19, can be seen from the biological, psychological, and social aspects. However, it is still necessary to conduct a deep investigation into experiences of pregnant, delivery, and postpartum women confirmed by Covid-19. 


\section{Pendahuluan}

World Health Organization (WHO) menyebut coronavirus disease yang ditemukan pertama kali di Wuhan dengan novel coronavirus 2019 (2019-nCoV) yang disebabkan oleh virus Severe Acute Respiratory Syndrome Coronavirus-2 (SARS-CoV-2). Sindrom pernapasan akut yang parah juga dikenal sebagai Corona Virus Disease 2019 atau Covid-19, telah dianggap darurat dalam kesehatan masyarakat di seluruh dunia (Zhu et al., 2020). Ibu hamil, bersalin, nifas dan bayi baru lahir juga merupakan sasaran yang rentan terhadap infeksi Covid-19 (Kemenkes RI, 2020). Penelitian Sheng (2020) juga menyebutkan bahwa ibu hamil dapat dianggap sebagai populasi yag beresiko terkena infeksi Covid-19 karena virus tersebut sangat pathogen dan virus Covid-19 mempunyai efek pada kehamilan (Sheng, 2020).

Kondisi kehamilan juga menyebabkan penurunan kekebalan parsial karena perubahan fisiologi pada saat kehamilan, yang mengakibatkan ibu hamil lebih rentan terhadap infeksi virus (D. Liu et al., 2020). Perubahan fisiologis dan imunologis yang terjadi sebagai komponen normal kehamilan dapat memiliki efek sistemik yang meningkatkan risiko komplikasi obstetrik dari infeksi pernapasan pada ibu hamil (Schwartz, 2020). Ibu hamil dengan Covid-19 menunjukkan bahwa tidak terjadi penularan vertikal intrauterine. Virus Covid-19 tidak ada dalam cairan ketuban, plasenta, air susu ibu (ASI) atau dalam sekresi hidung neonatus (Chen et al., 2020). tetapi infeksi dapat terjadi pada neonatus melalui kontak jarak dekat saat postnatal (Dashraath et al., 2020).

Covid-19 juga tidak terdeteksi pada ASI yang berstatus pasien Covid-19. Namun, fokus utama kekhawatiran adalah apakah wanita yang terinfeksi dapat menularkan virus melalui tetesan pernapasan selama menyusui (Rasmussen et al., 2020). Wabah pandemi ini memiliki dampak negatif pada kesehatan fisik dan psikologis individu dan masyarakat (Banerjee, 2020). Masa kehamilan, persalinan, dan postpartum merupakan masa yang rentang dengan adanya gangguan psikologi pada ibu, baik saat pandemi maupun tidak. Selain faktor kerentanan terhadap penularan virus, kondisi kesehatan mental ini dapat diperburuk oleh kurangnya dukungan keluarga secara langsung dan

\footnotetext{
* Korespondensi penulis.

Alamat E-mail: anonim@mail.com
}

dukungan sosial selama kehamilan, persalinan, dan periode postpartum (Bender et al., 2020).

Dampak pengalaman pandemi ini belum diketahui terhadap kesehatan mental dan reproduksi, tetapi ada konsensus bahwa selama kehamilan, persalinan dan nifas, wanita dihadapkan pada perubahan fisik, psikologis, dan emosional yang besar, pandemi seperti ini adalah sumber kecemasan, kesedihan, dan ketakutan, selain kehamilan dan ketidakpastian terkait penyakit (Dotters-Katz \& Hughes, 2020). Memahami pengalaman ibu hamil, bersalin dan nifas yang terinfeksi Covid-19 merupakan isu penting untuk pengembangan strategi intervensi untuk promosi, pencegahan, dan pemulihan kesehatan komprehensif (Freitas-Jesus et al., 2020).

\section{Metode penelitian}

Tinjauan cepat atau rapid review adalah jenis sintesis pengetahuan langkah-langkah tinjauan sistematis disederhanakan atau dipercepat untuk menghasilkan bukti dalam jangka waktu singkat (Langlois et al., 2017). merupakan jenis sintesis pengetahuan dimana langkah-langkah tinjauan sistematis disederhanakan atau dipercepat untuk menghasilkan bukti dalam jangka waktu yang lebih singkat. Selain itu, rapid review sebagai pendekatan yang berguna untuk memberikan bukti yang dapat ditindaklanjuti dan relevan secara tepat waktu dan hemat biaya (Tricco, Langlois and Straus, 2016). Tahapan mengenai penyusunan rapid review adalah berikut:

\section{Langkah 1 : Menetapkan Pertanyaan Review}

Perumusan pertanyaan penelitian ini menggunakan framework model PEO (Population, Exposure, dan Outcome) dalam mengelola dan memecahkan fokus review. Pertanyaan penelitian ini ditentukan dengan menggunakan framework dari Khanet al., (2003).

Tabel 1. Framework

\begin{tabular}{lll}
\hline Population & Exposure & Outcome \\
\hline Women & Covid-19 & Experience \\
Mother & Virus & Biopsychosocial \\
Pregnancy & Corona & Biology \\
Pregnant & Pandemic & Psychology \\
Postnatal & & Social \\
Postpartum & & Psychosocial \\
Perinatal & \\
Neonatal & \\
Delivery & & \\
Breastfeeding & & \\
\hline
\end{tabular}




\section{Langkah 2: Identifikasi Literatur yang Relevan}

Setelah mengidentifikasi pertanyaan rapid review, langkah selanjutnya adalah mengidentifikasi artikel yang relevan. Hal ini dilakukan dengan menentukan parameter kunci, seperti: Kriteria Inklusi Dan Kriteria Eksklusi

Tabel 2. Kriteria Inklusi dan Eksklusi

\begin{tabular}{|c|c|c|}
\hline \multicolumn{2}{|c|}{ Kriteria Inklusi } & Kriteria Eksklusi \\
\hline 1. & Original artikel & 1. Rapid Original \\
\hline 2. & $\begin{array}{l}\text { Artikel diterbitkan dalam Bahasa } \\
\text { Inggris atau Bahasa Indonesia }\end{array}$ & $\begin{array}{l}\text { 2. Review/ comment } \\
\text { article }\end{array}$ \\
\hline 3. & $\begin{array}{l}\text { Artikel diterbitkan dari tahun } \\
2019-2020\end{array}$ & 3. Artikel Opini \\
\hline 4. & $\begin{array}{lrr}\text { Artikel yang } & \text { membahas } & \text { tentang } \\
\text { pengalaman } & \text { ibu } & \text { yang } \\
\text { terkonfirmasi } & \text { Covid-19 } & \text { selama } \\
\text { hamil, bersalin dan nifas. } & \end{array}$ & \\
\hline 5. & $\begin{array}{l}\text { Artikel yang membahas tentang } \\
\text { aspek biologi, psikologi, sosial } \\
\text { (Biopsikososial) pada ibu hamil, } \\
\text { bersalin dan nifas yang } \\
\text { terkonfirmasi covid-19 }\end{array}$ & \\
\hline
\end{tabular}

Dalam pencarian artikel menggunakan tiga database (Pubmed, Ebsco, Wiley, Science Direct) dan Gray Literature dari Google Scholar. Strategi pencarian literature dengan menggubakan kata kunci yaitu "Women OR Mother OR Pregnancy $O R$ Pregnant OR Postnatal OR Postpartum OR Neonatal OR Delivery OR Breastfeeding AND Covid19 OR Corona virus OR Pandemic AND Experience OR Biopsychosocial OR Biology OR Psychology OR Social".

\section{Langkah 3: Pemilihan Studi}

Dalam pencarian 4 database dan reference list didapatkan jumlah artikel 1188 kemudian beberapa artikel yang double/duplikat yaitu 347 artikel. Dari 841 artikel dilakukan penyaringan berdasarkan title dan review artikel yang berhubungan dengan ibu hamil bersalin dan nifas yang terkonfirmasi Covid-19 sebanyak 268 artikel dan yang tidak relevan sebesar 573. Dilakukan penyaringan kembali berdasarkan abstrak untuk mendapatkan artikel yang sesuai, didapatkan 126 artikel dan 142 yang tidak sesuai. Pencarian full text yang teridentifikasi dilakukan untuk penyaringan isi artikel yang berdasarkan kriteria inklusi dan eksklusi, kesesuaian populasi, metode, dan hasil didapatkan 12 artikel yang akan digunakan untuk Rapid Review dan 114 artkel dihilangkan karena tidak sesuai.

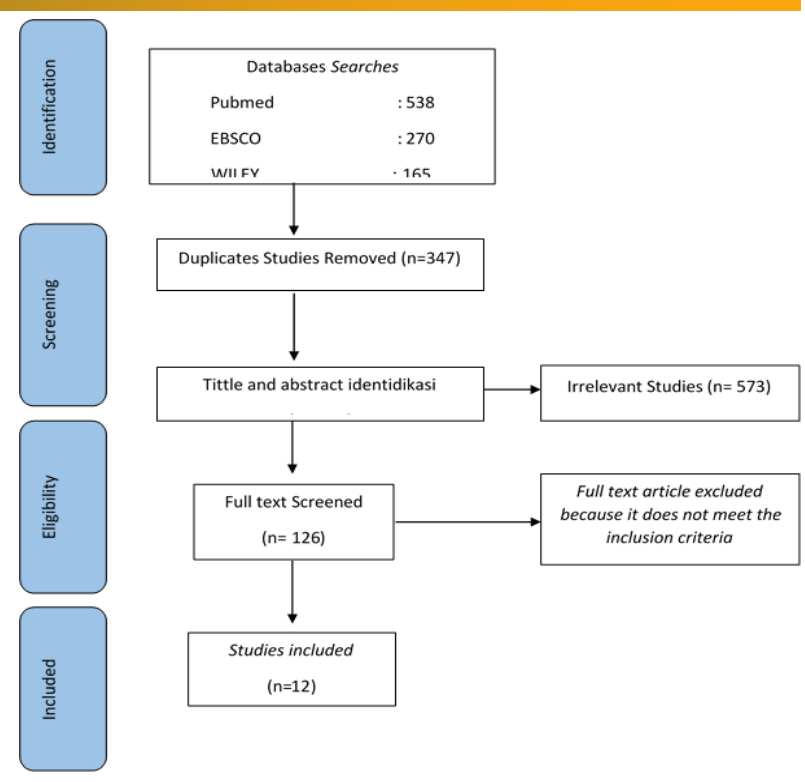

\section{Critical Appraisal}

Setelah proses peyeleksian artikel, kemudian artikel yang terseleksi dikritisi untuk mengetahui kualitas artikel yang dipilih. Alat bantu penilaian kritis yang digunakan Mix-Methods Appraisal Tools (MMAT) versi 2018. MMAT memiliki 7 petanyaan untuk setiap desain penelitian dan menyediakan 3 kriteria jawaban, yaitu "yes" untuk jawaban yang jelas, "no" untuk jawaban yang tidak tercantum dalam artikel dan "can't tell" untuk informasi yag tidak jelas terkait dengan kriteria yang ditanyakan. Peneliti memberikan skor pada setiap kriteria jawaban untuk memudahkan pemberian penilaian, yaitu jawaban "yes" dengan skor 3 dan "can't tell" dengan skor 2 dan "no" dengan skor 1.

Berdasarkan penilaian kritis menggunakan MMAT, dari 12 artikel yaitu 3 artikel kualitatif, 8 artikel kuantitatif dan 1 mix method. Dari 3 artikel kualitatif skor tertinggi 19/21 [1] karena penjelasan artikel yang jelas, metodenya runtut dan jelas, 2 artikel lainnya yaitu 18/21 [5] dan $17 / 21$ [12]. Artikel mix-method skor nya adalah 18/21 [4]. Artikel Kuantitatif sebanyak 8 artikel yaitu dengan penilaian berikut 18/21 [2][6][7][9], $17 / 21$ [3][8][10] dan skor terendah 16/21[11] Memiliki skor terendah karena penjabaran data kurang detail. 
Langkah 4: Data Charting

\begin{tabular}{llll}
\hline No Nama peneliti/ Tahun / Judul & $\begin{array}{l}\text { Lokasi } \\
\text { penelitian }\end{array}$ & Tujuan Penelitian & Desain penelitian \\
\hline 1 & $\begin{array}{l}\text { (Mizrak and Nur, 2020)/ The experiences of } \\
\text { pregnant women during the Covid-19 pandemic } \\
\text { in Turkey: A qualitative study }\end{array}$ & $\begin{array}{l}\text { Dalam penelitian bertujuan Kualitatif } \\
\text { melihat untuk perhatian, } \\
\text { masalah, dan sikap ibu hamil } \\
\text { terkait penyakit dalam proses } \\
\text { pandemi akan ditentukan oleh } \\
\text { diskusi terperinci berdasarkan } \\
\text { pengalaman masing-masing, dan } \\
\text { dengan meningkatkan kesadaran } \\
\text { bidan dan perawat tentang apa } \\
\text { yang dialami ibu hamil dalam } \\
\text { kehamilannya. }\end{array}$ &
\end{tabular}

(Barresi et al., 2020)/ Vaginal delivery in SARS CoV-2-infected pregnant women in Northern

Italy: a retrospective analysis

(Cao, Chen, et al., 2020)/ Vaginal delivery in China women with Covid-19: report of two cases (Brown and Shenker, 2020)/ Experiences of Inggris breastfeeding during Covid-19: Lessons for

future practical and emotional support

González-timoneda et al., 2020)/ Experiences Spanyol and attitudes of midwives during the birth of a pregnant woman with Covid-19 infection: A qualitative study.

\author{
(1)
}

is

Untuk melaporkan cara persalinan dan hasil neonatal

langsung pada wanita yang terinfeksi Covid-19.

Studi ini melaporkan diagnosis Case Report 2 ibu hamil dan proses pengobatan dua ibu positif Covid-19.

hamil terinfeksi Covid-19 yang pernah melahirkan pervaginam

Meneliti pengalaman wanita Mix-Method dengan bayi di bawah usia 1 tahun untuk memahami bagaimana Pendemi Covid -19 memengaruhi sikap, pilihan, dan hasil pemberian makan bayi mereka. Pemahaman yang lebih baik tentang dampak ini akan memandu praktik dan kebijakan terkait dengan mendukung ibu hamil dan baru melahirkan.

Untuk mengetahui pengalaman Kualitatif dan sikap bidan yang telah memberikan kehamilan dan perawatan persalinan untuk
Wanita yang terinfeksi SARS-CoV-2 yang dirawat dan dilahirkan dari 1 hingga 20 Maret 2020 memenuhi syarat di 12 Rumah sakit di Italia Utara.

Wanita yang terkonfirmasi Covid-19 yang akan melahirkan di Rumah Sakit Hubei, China.

Data dikumpulkan selama 4 minggu selama Mei - Juni 2020. Iklan ditempatkan di media sosial dengan mendorong organisasi menyusui untuk membagikan kiriman tersebut. Menggunakan kuesioner yang berisi pertanyaan tertutup dan terbuka, yang diselenggarakan secara online oleh Qualtrics.

Dilakukan di 2 rumah sakit Spanyol, memilih informan bidan dengan purposive sampel lalu data dikumpulkan dengan wawancara mendalam. 

outcomes of large series of SARS-CoV-2 positive pregnancies in peripartum period: A single-center prospective comparative study

(Mcdonnell et al., 2020)/ The impact of the Irlandia Utara Covid-19 pandemic on maternity services: A review of maternal and neonatal outcomes before, during and after the pandemic.

(Cao, Yin, et al., 2020)/ Clinical analysis of ten pregnant women with Covid-19 in Wuhan, China: A retrospective study
(Breslin et al., 2020)/Coronavirus disease 2019 infection among asymptomatic and symptomatic pregnant women: two

weeks of confirmed presentations to an affiliated pair of

New York City hospitals.
Untuk menggambarkan proporsi penyakit asimtomatik, ringan dan berat pada ibu hamil yang terinfeksi yang dirawat di persalinan. Untuk

membandingkan hasil ibu, janin dan neonatal dari ibu hamil yang terinfeksi SARS-CoV-2 dengan pasien yang tidak terinfeksi

Untuk mengeksplorasi tren yang terlihat dalam hasil ibu atau bayi selama pandemi Covid-19 dengan membandingkan hasil kehamilan sebelum, selama dan setelah pandemi.

Penelitian ini bertujuan untuk mengevaluasi karakteristik klinis dan hasil akhir kehamilan ibu hamil terkonfirmasi Covid-19 untuk memberikan referensi untuk pekerjaan klinis.

Tujuan penelitian ini adalah Cohort prospektif untuk mengetahui karakteristik klinis neonatus yang lahir dari ibu yang terinfeksi SARS-CoV-2 dan meningkatkan pengetahuan saat ini tentang konsekuensi perinatal dari Covid-19

Amerika Serikat Menyajikan pengalaman kasus Covid-19 positif selama kehamilan di rumah sakit ofNewYork City.
Cohort prospektif

Data dikumpulkan Melalui tes PCR universal untuk SARS-COV-2 saat masuk (bukan berdasarkan gejala). ini mengikutsertakan semua wanita hamil yang dirawat untuk persalinan antara 16 Juni dan 16 Agustus 2020 di Pusat Rumah Sakit Guiana Prancis Barat.

Statistik database maternitas yang tercata di rumah sakit pusat rujukan di Dublin Irlandia.

Wanita hamil Terkonfirmasi Covid-19 d beberapa Rumah Sakit Kesehatan Ibu dan Anak Provinsi Hubei, dari 23 Januari hingga 23 Februari 2020

Semua wanita hamil yang didiagnosis secara klinis atau dikonfirmasi laboratorium dengan Covid-19 selama kehamilan lanjut, dan melahirkan bayi mereka di Rumah Sakit Tongji antara 31 Januari dan 29 Februari,

2020 dimasukkan dalam penelitian ini.

Ibu hamil yang dikonfirmasi Covid-19 yang akan bersalin atau dirujuk karena akan besalin selama dirawat dalam Rumah sakit tersebut. 
11

(Wu, 2020)/ Coronavirus disease 2019 among Cina pregnant

Chinese women: case series data on the safetyof vaginal birth and breastfeeding.

A study of breastfeeding practices, SARS-CoV-2 and its antibodies in the breast milk of mothers confirmed with COVID-19
Untuk menilai apakah sekresi Kohort

vagina dan ASI dari wanita

dengan (Covid-19) mengandung

virus (SARS-CoV-2).

Penelitian ini bertujuan untuk Kualitatif mengeksplorasi hasil kesehatan dan perkembangan jangka pendek dan menengah dari neonatus yang lahir dari ibu yang dikonfirmasi Covid-19.
Wanita hamil yang terinfeksi SARS-CoV-2 yang didiagnosis antara 31 Januari dan 9 Maret 2020. mengumpulkan data klinis, sekresi vagina, spesimen feses, dan ASI dari wanita yang terinfeksi

Pengumpulan data berbasis telepon dilakukan pada hari ke $3,7,14,28,42$, dan 56 setelah persalinan untuk mengumpulkan informasi tentang praktik menyusui,

termasuk metode pemberian makan (ASI eksklusif atau pemberian ASI perah, menyusui atau pemberian ASI perah dicampur dengan pemberian susu formula, dan hanya pemberian susu formula), harihari pemisahan ibu-anak, dan waktu mulai menyusui atau menyusui dengan ASI, jika ada. Sampel ASI dikumpulkan dari 16 dari 24 ibu yang dikonfirmasi Covid-19 untuk pengujian asam nukleat dan antibodi (IgM dan IgG) SARS-CoV-2. 


\section{Hasil dan Pembahasan}

Hasil

Berdasarkan 12 artikel yang di gunakan terdapat 5 artikel dari negara Cina artikel lainnya berasal dari negara Turki, Itali, Inggris, Spanyol, Perancis, Irlandia Utara dan Amerika Serikat. Berdasarkan desain penelitian yaitu desain penelitian kuantitatif berjumlah 8 artikel, desain penelitian kualitatif 3 artikel dan desain penelitian mix method 1 artikel. Berdasarkan 12 artikel yang di gunakan terdapat 3 tema yaitu Ibu Hamil dengan Covid-19, Ibu Bersalin dengan Covid-19, Ibu Nifas dengan Covid-19.

Tabel 3. Mapping Literature

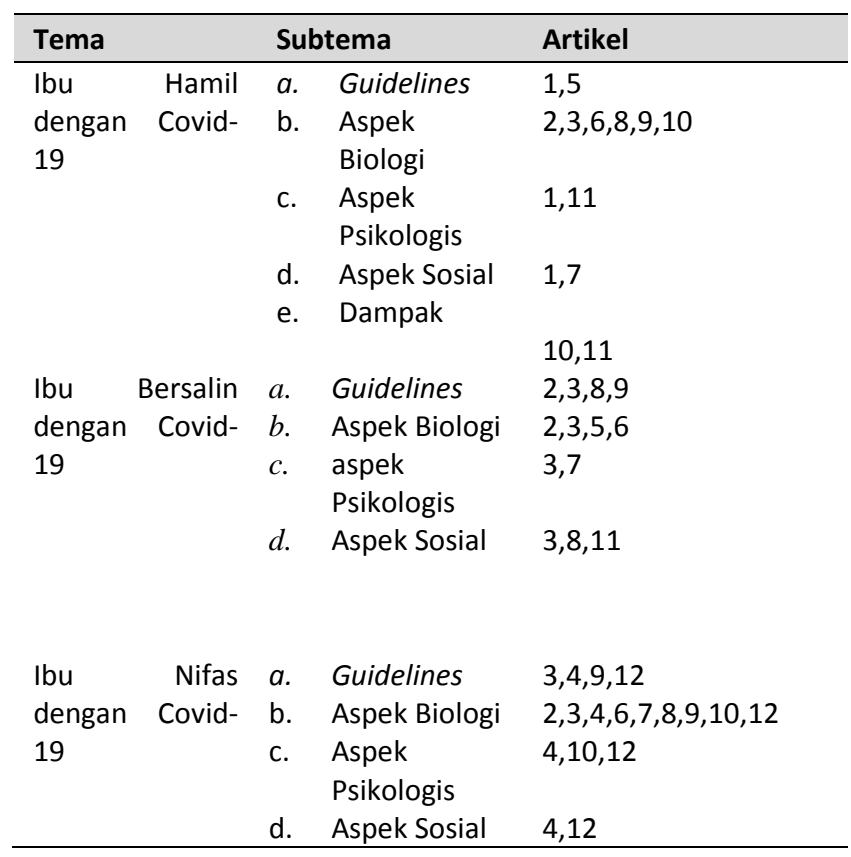

\section{Pembahasan}

\section{Ibu Hamil dengan Covid-19}

\section{a. Guidelines}

Pandemi virus corona dan gangguan perawatan Antenatal Care (ANC) rutin, Untuk mengurangi risiko infeksi akibat pandemi, kebijakan nasional telah mengusulkan periksa dengan dukungan jarak jauh semaksimal mungkin (Mizrak and Nur, 2020). Pemeriksaan antenatal selama kehamilan dianjurkan minimal $6 x$ tatap muka tanpa melihat status zona covid-19 daerah tersebut, dan dapat ditambahkan pemeriksaan telemedicine sesuai kebutuhan (POGI, 2020). Satu kali kunjungan pertama di trimester 1 jika ibu datang pertama kali ke bidan, bidan tetap melakukan pelayanan antenatal seperti biasa, tetapi sebelum ibu melakukan kunjungan antenatal secara tatap muka, dilakukan janji temu atau teleregistrasi dengan skrining anamnesa melalui media komunikasi (telepon) atau secara daring untuk mencari faktor risiko dan gejala Covid-19 (Kemenkes RI, 2020).

Penundaan Periksa kehamilan, ibu hamil diperingatkan oleh dokternya untuk tidak pergi ke rumah sakit kecuali ada pemeriksaan wajib, tes atau ada kesulitan (Mizrak and Nur, 2020). Pemeriksaan ANC seperti yang sudah disarankan sampai trimester 3, Ibu dengan gejala Covid-19 harus diuji dan Pemeriksaan ANC ditunda jika memungkinkan, selama periode karantina sendiri, jika gejala berlanjut, mereka harus menghubungi dan membuat janji untuk tes dan / atau perawatan rumah sakit (Ryan et al., 2020). Disarankan untuk melanjutkan asuhan antenatal rutin meskipun terdapat beberapa modifikasi, kecuali ibu hamil yang memerlukan isolasi mandiri karena dicurigai atau sudah terkonfirmasi Covid-19 (POGI, 2020). Dukungan tenaga kesehatan Selama pandemi, ibu hamil yang dengan mudah menghubungi dokter, bidan, dan perawatnya serta mendapat dukungan telepon atau online menyatakan bahwa mereka merasa lebih nyaman (Mizrak and Nur, 2020).

Ibu hamil suspect, probable, dan terkonfirmasi Covid-19, saat pelayanan antenatal mulai diberikan penjelasan KIE mengenai pilihan IMD, rawat gabung, dan menyusui agar pada saat persalinan sudah memiliki pemahaman dan keputusan untuk perawatan bayinya (Kemenkes RI, 2020). Pemberian Tablet Tambah Darah (TTD) bagi ibu hamil dengan status suspect, probable atau terkonfirmasi positif Covid-19 dilakukan dengan pertimbangan dokter yang merawat dan kondisi pasien yang bersangkutan (POGI, 2020). Selanjutnya Ibu hamil yang telah pulih dari Covid19, tindak lanjut yang dekat disarankan dengan penilaian regular dari pertumbuhan janin dan kesejahteraan karena data yang kurang tentang potensi perkembangan hambatan pertumbuhan intrauterin (IUGR) dan insufisiensi plasenta (Kemenkes RI, 2020).

\section{b. Aspek Biologi}

Domain biologis kesehatan berfokus pada fisiologis dan masalah biomedis yang mencakup pertimbangan terkait untuk kondisi dan gejala akut dan kronis, diagnosis kesehatan,obat-obatan, perawatan medis, dll (Soma-pillay et al., 2016). Efek Covid-19 pada wanita hamil masih belum diketahui hingga saat ini. Karena perubahan 
fisiologis ibu yang normal dan penekanan kekebalan selama masa hamil, wanita ini sangat rentan terhadap patogen pernapasan (Cao, Yin, et al., 2020). Penting untuk diketahui bahwa beberapa bersifat fisiologis terkait dengan Covid19 Perubahan dalam kehamilan bisa meniru gejala medis penyakit misalnya sesak napas, dan perubahan fisiologis mungkin juga membuat wanita lebih rentan terhadap penyakit misalnya perubahan sistem kekebalan (Diamond et al., 2020).

Tanda klinis dan biologis ibu hamil Covid-19 yang didiagnosis dengan infeksi Covid-19 saat masuk rumah sakit hanya $24,8 \%$ dari pasien positif yang menunjukkan gejala klinis Covid-19 (Hcini et al., 2020). Demam adalah gejala yang paling umum dialami ibu hamil yang terkonfirmasi Covid-19, ada juga dengan batuk sesak atau diare (Barresi et al., 2020). Sejalan dengan penelitian W. Liu et al., (2020) sebagian besar ibu hamil yang terkonfirmasi Covid-19 memiliki gejala demam (W. Liu et al., 2020). Demam 37,8 C (100,0 F), batuk kering dan sakit kepala juga gejala yang dialami ibu hamil yang Covid-19 (Breslin et al., 2020).

Ibu mempunyai riwayat batuk kering dan pilek selama seminggu (Cao, Chen, et al., 2020). Gejala Covid-19 lainnya yang paling umum adalah demam, rasa lelah, dan batuk kering. Beberapa pasien mungkin mengalami rasa nyeri dan sakit, hidung tersumbat, pilek, nyeri kepala, konjungtivitis, sakit tenggorokan, diare, hilang penciuman dan pembauan atau ruam kulit (POGI, 2020). Ibu hamil didiagnosis COVID-19 mengalami gejala ringan ibu hamil mengalami demam dan batuk (Cao, Yin, et al., 2020).

Sejalan dengan dengan penelitian Hcini et al., (2020) ibu hamil dengan Covid-19 juga mengalami gejala seperti demam, sakit kepala, batuk, diare, kehilangan rasa dan bau juga kelelahan dan juga sesak nafas. sebagian besar ibu hamil tersebut ada yang tidak memiliki gejala apapun (Hcini et al., 2020). Ibu hamil yang dirawat untuk melahirkan dan didiagnosis dengan infeksi Covid-19 melalui pemeriksaan universal hanya menunjukkan gejala pada seperempat kasus. Risiko perdarahan post partum, transfusi dan masuk ke ICU lebih tinggi daripada pasien yang tidak terinfeksi dan risiko kematian janin intrauterus yang lebih tinggi (Hcini et al., 2020).

\section{c. Aspek Psikologi}

Ranah psikologis kesehatan meliputi pikiran, perasaan, dan perilaku yang biasanya dipertimbangkan saat menilai kesehatan mental. Banyak yang telah ditulis tentang dampak psikologis dari periode perinatal (Slade et al., 2009). "kehamilan bukanlah waktu yang biasa dalam hidup dari seorang wanita. Tidak ada titik lain dalam hidupnya yang akan begitu banyak perubahannya dalam waktu singkat, akan sifat dan kualitas adaptasinya memiliki implikasi yang sangat luas untuk dirinya sendiri dan anaknya secara fisik dan psikologis kesehatan". Pandemi Covid-19 ini memiliki dampak negatif pada kesehatan fisik dan psikologis individu dan masyarakat (Banerjee, 2020). Merebaknya virus Covid-19 disisi lain juga telah menimbulkan stres dan kecemasan bagi ibu hamil di berbagai belahan dunia (Bayrampour et al., 2015).

Masa kehamilan adalah saat-saat yang sangat rentan secara psikologis kesusahan dapat memiliki konsekuensi negatif bagi ibu dan bayinya. Karena ibu cenderung melaporkan gejala kecemasan dan depresi yang lebih tinggi selama wabah penyakit dibandingkan laki-laki (Masjoudi et al., 2020). Ibu hamil mengalami ketakutan, terutama karena risiko infeksi virus dan tentang pemeriksaan kehamilan (Mizrak and Nur, 2020). Pandemi Covid-19 yang belum pernah terjadi sebelumnya, sehingga terjadi krisis psikologis yang bisa dimengerti karena ini adalah masa ketidakpastian dan kecemasan yang diperburuk dengan kekhawatiran terkait kesehatan dan perubahan pada pemeriksaan kehamilan (Diamond et al., 2020). Kecemasan dan ketakutan alasan terpenting para ibu mengalami ketakutan dan kecemasan adalah karena mereka hamil, tidak bisa menahan rasa cemas karena ibu berfikir jika saya terpengaruh, bayi saya akan terpengaruh (Mizrak and Nur, 2020).

Hasil penelitian menunjukkan bahwa pandemi virus Corona memiliki arti yang signifikan berpotensi untuk menimbulkan kecemasan, kesulitan dan ketakutan, yang memiliki efek emosional negatif pada wanita hamil (Mizrak and Nur, 2020). Ibu hamil yang terkonfirmasi Covid-19 dapat mengalami penderitaan psikologis yang hebat, yang dapat menyebabkan konsekuensi serius dalam hal kesehatan mental (Dotters-Katz \& Hughes, 2020). Hal ini sesuai dengan studi yang dilakukan di Wuhan China ditemukan 53,8\% ibu 
hamil mengalami gangguan psikologis dengan $17 \%$ dan 29\% mengalami depresi berat dan gejala kecemasan (Zhao et al., 2020). Peningkatan kecemasan pada masa kehamilan dan gejala depresi akan meningkatkan risiko postpartum depresi, serta infeksi prenatal dan tingkat penyakit (L. M. Lim et al., 2020).

\section{d. Aspek Sosial}

$\begin{array}{ccr}\text { Domain } & \text { sosial } & \text { kesehatan } \\ \text { mempertimbangkan hubungan dan kondisi }\end{array}$ lingkungan seseorang, yang sangat terbatas untuk semua karena risiko seputar Covid-19 dan khususnya untuk populasi yang rentan seperti ibu hamil (Diamond et al., 2020). Gangguan sosial dan isolasi selama proses pandemi, ibu hamil yang pasangannya aktif bekerja dipisahkan dari pasangannya karena risiko tertular virus, atau mereka mematuhi aturan jarak sosial dengan pasangannya (Mizrak and Nur, 2020). Salah satu bentuk perubahan perilaku yang ditunjukkan antara lain adalah isolasi social. Perilaku isolasi diri selama pandemi Covid-19 yang berhubungan juga dengan masalah psikologis berupa ketakutan/kecemasan (Topalidou \& Thomson, 2020).

Kehamilan selama Covid-19, pedoman utama termasuk jarak sosial dan isolasi, terutama setelah usia kehamilan 28 minggu (Mahajan et al., 2020). Pedoman jarak sosial, secara keseluruhan, menjadi perhatian psikososial. Penelitian menunjukkan hubungan yang signifikan antara isolasi sosial (yaitu, kurangnya interaksi dengan orang lain atau komunitas yang lebih luas) dan kesepian (yaitu, perasaan tidak adanya jaringan sosial atau pendamping) dengan mental yang lebih buruk, yaitu seperti depresi (Langlois et al., 2017). Kondisi kesehatan mental ini dapat diperburuk oleh kurangnya dukungan keluarga secara langsung dan dukungan sosial selama kehamilan (Bender et al., 2020).

Dukungan keluarga penting dalam proses kehamilan karena biasanya ibu dari wanita hamil tinggal bersamanya dalam proses ini dan membantunya membuat proses itu lebih nyaman. Namun, karena pandemi, banyak keluarga ibu hamil tidak dapat tinggal bersama mereka karena tindakan nasional seperti pembatasan jarak atau Social distancing prosesnya lebih sulit untuk wanita hamil (Mizrak and Nur, 2020). Tidak hanya gangguan pada dukungan keluarga kemampuan untuk terlibat secara sosial dengan sistem pendukung juga penting,ada perubahan pada hubungan ibu dengan penyedia layanan kesehatan. yakni, telah terjadi gangguan pemeriksaan ANC pengurangan janji tatap muka, dan peningkatan penggunaan telehealth (Karavadra et al., 2020).

\section{e. Dampak}

Perubahan imunologis sistemik pada kehamilan yang berpotensi berdampak pada fungsi paru-paru, perubahan anatomi juga terjadi pada sistem pernapasan. Perubahan fisiologis pada bentuk dada dan peninggian diafragma akibat belat diafragma oleh rahim yang sedang hamil menyebabkan perubahan pada fungsi pernapasan. Meskipun ada peningkatan $30-40 \%$ dalam volume tidal, penurunan volume dada menyebabkan penurunan kapasitas residu fungsional, volume ekspirasi akhir, dan volume sisa sejak awal kehamilan. Penurunan kapasitas total paru-paru dan ketidakmampuan untuk mengeluarkan sekresi dapat membuat wanita hamil lebih rentan terhadap infeksi saluran pernapasan yang parah (Lim, Macfarlane and Colthorpe, 2010). SARS-CoV2 dan awal kehamilan hanya ada sedikit bukti tentang kemungkinan dampak Covid-19 pada awal kehamilan (hingga usia kehamilan 12 minggu). yaitu Influenza musiman dikaitkan dengan tingkat keguguran yang lebih tinggi (Dorélien, 2019) terdapat peningkatan risiko keguguran pada wanita hamil yang terkonfirmasi Covid-19 (Krupa et al., 2020).

Covid-19 dan kehamilan lanjut ekstrapolasi dari efek virus lain pada akhir kehamilan (kehamilan lebih dari 24 minggu). Hal ini menunjukan bahwa infeksi Covid-19 dapat menyebabkan peningkatan tingkat hasil kehamilan yang merugikan seperti hambatan pertumbuhan janin, kelahiran prematur dan kematian perinatal (Dorélien, 2019). selain itu juga terkait penularan vertikal tetapi belum cukup bukti penularan vertikal atau penularan virus melalui ASI (Breslin et al., 2020). Pendapat klinis para ahli menunjukkan bahwa infeksi SARS-CoV-2 ini adalah hasil dari kontak dekat dengan individu yang terinfeksi daripada penularan vertikal (Wu, 2020).

\section{Ibu Bersalin dengan Covid-19}

\section{a. Guidelines}

Persalinan Ibu yang terkonfirmasi Covid-19 tempatkan pasien yang telah terkonfirmasi Covid19 , probable, atau suspek dalam ruangan khusus 
(ruangan isolasi infeksi airborne) yang sudah disiapkan sebelumnya bagi fasilitas pelayanan kesehatan yang sudah siap atau sebagai pusat rujukan pasien Covid-19. Jika ruangan khusus ini tidak ada, pasien harus sesegera mungkin dirujuk ke tempat yang ada fasilitas ruangan khusus tersebut. Perawatan maternal dilakukan di ruang isolasi khusus ini termasuk saat persalinan dan nifas (Kemenkes RI, 2020). Ibu hamil positif covid yang akan bersalin pervaginam dipindah ke ruang bersalin isolasi yang ditunjuk dan diberi masker bedah untuk menghindari tetesan (Cao, Chen, et al., 2020). Hanya satu orang (pasangan/anggota keluarga) yang dapat menemani ibu bersalin. Orang yang menemani harus diinformasikan mengenai risiko penularan dan mereka harus memakai APD yang sesuai saat menemani pasien. Idealnya penunggu pasien juga harus dilakukan skrining risiko Covid-19 (POGI, 2020).

Proses persalinan ibu dengan Covid-19 diizinkan untuk melahirkan bayi mereka di ruang isolasi (Cao, Yin, et al., 2020). Penjepitan tali pusat yang tertunda dan kontak kulit-ke-kulit antara ibu dan bayi tidak diizinkan dalam kasus ibu bersalin dengan terkonfirmasi Covid-19 (Cao, Chen, et al., 2020). Persalinan pervaginam tepat untuk kasus ibu terkonfirmasi Covid-19 yang ringan dan operasi caesar harus dilakukan untuk wanita dengan masalah pernapasan yang parah, dimana melahirkan bayi akan memungkinkan peningkatan ventilasi (Barresi et al., 2020).. Persalinan terjadi di ruang isolasi dan neonatus langsung dipisahkan dari ibunya dan diisolasi minimal selama 14 hari (W. Liu et al., 2020). Sejalan dengan penelitian (Cao, Chen, et al., 2020) setelah dievaluasi oleh ahli neonatologi, bayi yang baru lahir segera dipindahkan ke bangsal isolasi neonatal, dan ibu juga dipindahkan ke bangsal lain yaitu ruang isolasi setelah 2 jam observasi postpartum (Cao, Chen, et al., 2020).

Gejala Covid-19 tetap diamati setelah persalinan, prosedur yang aman untuk bidan dan dokter harus direkomendasikandalam persalinan apa pun serta mengadopsi masker dan prosedur yang aman (Barresi et al., 2020). Persalinan dengan ibu yang Covid-19 dengan operasi caesar terjadi di ruang operasi yang terisolasi. Semua ahli bedah, perawat, dan staf lain di ruang operasi mengenakan pakaian pelindung tingkat 3 (W. Liu et al., 2020). Metode persalinan pada ibu Covid-19 Sampai saat ini belum ada bukti kuat bahwa salah satu metode persalinan memiliki luaran yang lebih baik dari yang lain. Metode persalinan sebaiknya ditetapkan berdasarkan penilaian secara individual (kasus per kasus. Indikasi dilakukan induksi persalinan dan seksio sesaria dilakukan apabila ada indikasi medis atau obstetri sesuai kondisi ibu dan janin. Infeksi Covid-19 sendiri bukan indikasi dilakukan seksio sesaria (POGI, 2020).

Pelayanan persalinan status ibu dikaitkan dengan Covid-19. Persalinan di rumah sakit rujukan Covid-19 untuk ibu dengan status suspect, probable, dan terkonfirmasi Covid-19 (penanganan tim multidisiplin). (Kemenkes RI, 2020). Ibu hamil terkonfirmasi Covid-19 dengan gejala klinik (simptomatik) dirawat di ruang isolasi, dilakukan penanganan tim multidisiplin yang terkait, meliputi dokter paru atau penyakit dalam, dokter kandungan, anestesi, bidan, dokter neonatologis dan perawat neonatal (POGI, 2020). tetapi perlu digaris bawahi walaupun dengan segala panduan jika ibu positif Covid-19 jika ibu dengan kondisi inpartu atau emergensi harus diterima di semua fasilitas pelayanan kesehatan walaupun belum diketahui status Covid-19. Kecuali bila ada kondisi yang mengharuskan dilakukan rujukan karena komplikasi obstetrik (Kemenkes RI, 2020).

\section{b. Aspek Biologi}

Demam adalah gejala yang paling umum dialami ibu bersalin yang terkonfirmasi Covid-19 ada yang demam sebelum melahirkan dan juga ada yang demam setelah melahirkan, selain itu ada yang mengalami batuk sesak ataupun diare (Barresi et al., 2020). Sejalan dengan penelitian ini yaitu ibu melahirkan juga dalam keadaan batuk dan pilek sedai seminggu yang lalu (Cao, Chen, et al., 2020). tetapi ada juga ibu melahirkan pervaginam persalinan berjalan lancar tanpa demam (González-timoneda et al., 2020).

Selama persalinan rawat inap dan tindak lanjut setelah kembali ke rumah sebagian besar ibu yang terkonfirmasi Covid-19 tanpa gejala (Hcini et al., 2021). Belum didapatkan bukti bahwa persalinan pervaginam akan meningkatkan kemungkinan infeksi neonatal (Cao, Chen, et al., 2020). Ibu hamil dengan Covid-19 menunjukkan bahwa tidak terjadi penularan vertikal intrauterine. Virus Covid-19 tidak ada dalam cairan ketuban, plasenta, ASI atau dalam sekresi hidung neonatus (Chen et al., 2020). Tidak ada infeksi bayi baru lahir yang dilaporkan. Penularan vertikal 
tampaknya tidak terjadi setelah ibu terkonfirmasi dengan virus corona (Barresi et al., 2020). Tetapi tetap perlu diperhatikan bahwa ibu bersalin yang terinfeksi SARS-COV-2 memiliki peningkatan risiko hasil yang merugikan pada ibu (masuk ICU, perdarahan post partum dan transfusi) dan janin (kematian janin intrauterin) (Hcini et al., 2020).

\section{c. Aspek Psikologis}

Hamil lalu melahirkan, idealnya, merupakan peristiwa yang berhubungan dengan kegembiraan, namun beberapa wanita bisa mengalami emosi negatif selama periode ini, termasuk kecemasan dan depresi. Hamil dan melahirkan selama pandemi tidak hanya membawa risiko klinis bagi ibu dan bayi, tetapi juga stres psikologis (Topalidou \& Thomson, 2020). Dukungan bidan dan kehadiran tenaga medis juga pendampingan keluarga ibu bersalin dengan Covid-19, proses persalinan berjalan dengan lancar (Cao, Chen, et al., 2020). Satu orang (pasangan atau anggota keluarga) yang dapat menemani ibu bersalin (POGI, 2020). Ibu yang melahirkan umumnya dibatasi kepada satu orang pendukung yang sehat selama durasi persalinan. Ibu mendapat manfaat dari ini juga. Memiliki kasih sayang dan rekan kerja yang dapat dipercaya untuk memberikan dukungan terus menerus selama persalinan diketahui membuat perbedaan yang signifikan meningkatkan pengalaman melahirkan dan kesehatan dan kesejahteraan tentang ibu bersalin dan bayi (Rasmussen et al., 2020).

\section{d. Aspek Sosial}

Data dari 10 ibu hamil yang terkonfirmasi Covid-19 dan akan bersalin Di antara $10 \mathrm{ibu}$, dua ibu menjalani persalinan pervaginam, dua ibu menjalani operasi caesar intrapartum, dan enam ibu lainnya menjalani operasi caesar elektif (Cao, Yin, et al., 2020). Kurangnya pengetahuan tentang Covid-19 dan kekhawatiran tentang potensi penularan dari ibu ke anak sebagai faktor sosial menjadi indikasi operasi caesar pada tiga ibu hamil (Wu, 2020). Setelah ibu selesai melahirkan pervaginam, kami meminta pendapat orang tua tersebut tentang menyusui dan isolasi neonatal, dan mereka memutuskan untuk mengisolasi sementara dengan bayi baru lahir dan menangguhkan menyusui lalu dipindahkan ke bangsal isolasi yang ditunjuk setelah 2 jam observasi (Cao, Chen, et al., 2020).

\section{Ibu Nifas dengan Covid-19}

\section{a. Guidelines}

Setelah persalinan pervaginam lalu bayi dievaluasi oleh ahli neonatologi, bayi yang baru lahir segera dipindahkan ke bangsal isolasi neonatal, dan ibunya juga dipindahkan ke ruang isolasi setelah 2 jam observasi postpartum (Cao, Chen, et al., 2020). Untuk mengurangi transmisi virus dari ibu ke bayi, harus disiapkan fasilitas untuk perawatan terpisah pada ibu yang telah terkonfirmasi Covid-19 atau suspek dari bayinya sampai batas risiko transmisi sudah dilewati (Kemenkes RI, 2020). Ruang isolasi setelah 2 jam observasi postpartum (Cao, Chen, et al., 2020).

Ibu nifas dengan status suspek, probable, dan terkonfirmasi Covid-19 setelah pulang ke rumah melakukan isolasi mandiri selama 14 hari. Kunjungan nifas dilakukan setelah isolasi mandiri selesai (Kemenkes RI, 2020). kurangnya bukti penularan Covid-19 melalui ASI, petugas kesehatan harus memberikan konseling menyusui yang memadai bersama dengan tindakan pencegahan kebersihan tangan dan masker wajah yang tepat (Peng et al., 2020).

Ibu dengan konfirmasi Covid-19 menunda inisiasi menyusui atau memberi ASI perah kepada bayi sampai tiga minggu setelah melahirkan terutama karena tindakan isolasi dan karantina yang ketat (Peng et al., 2020). Ibu harus memompa secara teratur untuk memastikan laktasi (W. Liu et al., 2020). Ibu disarankan menggunakan memakai masker untuk menyusui bayinya saat mengalami gejala Covid-19 (Brown and Shenker, 2020). tetapi karena ketakutan sebagian besar ibu yang bersalin dengan Covid-19 memilih untuk memerah ASI (Peng et al., 2020).

\section{b. Aspek Biologi}

Pada masa nifas, ibu yang terinfeksi SARSCoV-2 sebanyak $14,2 \%$ lebih cenderung mengalami perdarahan post partum> $500 \mathrm{~mL}$ (Hcini et al., 2020). Bayi baru lahir dari ibu hamil yang terkonfirmasi Covid-19 dan menemukan bahwa mereka tidak menunjukkan gangguan pernapasan, demam, intoleransi makan, muntah atau kematian (Cao, Yin, et al., 2020).Bayi baru lahir pada ibu bersalin terkonfrimasi Covid-19 diikuti selama lebih dari 14 hari dan tidak ada yang mengalami gejala terkait Covid-19 (Cao, Chen, et al., 2020). Sejalan dengan hal tersebut ibu yang terkonfimasi Covid- 
19 lalu bersalin lalu bayi yang dilahirkan diamati pada periode 14 hari, tidak ada kematian neonatal atau asfiksia neonatal yang diamati, dan tidak ada yang mengalami demam, batuk, atau diare (Hcini et al., 2021).

Bayi baru lahir dari ibu yang terkonfirmasi Covid-19 diamati tidak ada yang mengalami asfiksia neonatal (Cao, Yin, et al., 2020). Tidak ada perbedaan dalam hasil klinis utama (berat lahir, skor APGAR, gangguan pernapasan, pemberian oksigen, masuk NICU, kejang neonatal, atau kematian neonatal) atau hasil neonatal biologis (laktat vena umbilikalis) antara ibu hamil dengan terkonfirmasi Covid-19 dan yang sehat Semua neonatus tetap sehat secara klinis dan tumbuh dengan baik (Hcini et al., 2021). Pemeriksaan Covid-19 RT-PCR pada usap tenggorokan, urin, dan feses dari semua neonatus negatif dalam ASI dan air ketuban juga negatif (W. Liu et al., 2020).

Tes asam nukleat SARS-CoV-2 pada tenggorokan neonatal dan usapan anal semuanya negatif pada hari ke-1 dan ke-3 setelah lahir ( $\mathrm{Wu}$, 2020). hasil penelitian dari Hcini et.,al (2020) seluruh neonatus sebanyak 108 dari ibu yang terinfeksi Covid-19 yang dites saat lahir, tidak ada yang positif SARS-CoV-2 (Hcini et al., 2020). Sejalan dengan hal tersebut bahwa neonatus pada ibu bersalin Covid-19 memiliki hasil tes negatif untuk Covid-19 (Breslin et al., 2020).

Sampel ASI dikumpulkan pada hari ke-6 dan ke-27 setelah melahirkan menunjukkan hasil negatif virus (Wu, 2020). Pendapat klinis para ahli menunjukkan bahwa infeksi Covid-19 ini adalah hasil dari kontak dekat dengan individu yang terinfeksi dari pada penularan vertikal (Mcdonnell et al., 2020). Sejalan dengan hal tersebut Penularan infeksi virus secara vertikal umumnya terjadipada periode postpartum melalui menyusui kontak ibu yang dekat mungkin merupakan jalur penularan yang potensial (Barresi et al., 2020).

\section{c. Aspek Psikologis}

Ibu yang melahirkan di isolasi melaporkan merasa lebih terpengaruh secara negatif oleh pandemi dan isolasi baik dalam hal perasaan bahwa mereka tidak mendapatkan cukup dukungan dan keterbatasan kontak sosial menghalangi mereka untuk mengakses layanan dukungan dan peluang sosial juga terkait dengan menyusui dan pemisahan perawatan dengan bayi (Brown and Shenker, 2020). Pemisahan ibu dan bayi dianggap berbahaya bagi perkembangan awal bayi dan dapat meningkatkan masalah fisik dan psikologis ibu (Peng et al., 2020).

\section{d. Aspek Sosial}

Domain kesehatan yang dijelaskan di atas tidak dapat dipisahkan saling berhubungan sehingga kesehatan seseorang dapat dipahami dengan baik dan diperlakukan di persimpangan domain biopsikososial (Brooks et al., 2020) Pemisahan perawatan tindakan ini kemungkinan besar mengakibatkan, yang kemungkinan besar berkontribusi pada penundaan menyusui dan penurunan produksi ASI (Peng et al., 2020). Dampak negatifnya berupa, dengan proporsi tinggi pada kelompok yang berhenti menyusui yang menganggap kurangnya dukungan sosial dan emosional ini berdampak negatif pada pengalaman menyusui mereka (Brown and Shenker, 2020). Hal ini membawa kita ke masalah jumlah perempuan yang berhenti menyusui selama Isolasi, banyak dari mereka tidak mengakses dukungan dan merasa bahwa perubahan dukungan secara langsung berdampak pada keputusan mereka untuk berhenti menyusui. (Brown and Shenker, 2020). karena bahkan dalam kondisi terbaik, transisi pascapartum bisa menyulitkan keluarga, karena ada banyak biopsikososial,perubahan sistemik dan pemicu stres (Corbett et al., 2020).

Permasalahan terkait Covid-19 seperti gangguan perawatan karena isolasi dan orang yang dicintai (orang tua, keluarga) tidak dapat mengunjungi kelahiran bayi (Thayer \& Theresa E. Gildner, 2020). Kesepian diciptakan oleh jarak sosial dapat berkembang dari penyebab stres psikososial lainnya dialami oleh ibu dan keluarganya setelah lahir. (Freitas-Jesus et al., 2020).

\section{Simpulan}

Berdasarkan hasil dan pembahasan ibu hamil, bersalin dan nifas yang terkonfirmasi Covid19 yaitu didapatkan ibu hamil terkonfirmasi Covid19 dari aspek biologi, aspek psikologi dan aspek sosial juga dampak terhadap kehamilan, selanjutnya ibu berssalin yang terkonfirmasi Covid19 dari aspek biologi, aspek psikologi, aspek social dan ibu nifas yang terkonfirmasi Covid-19 dari aspek biologi, aspek psikologi dan aspek social.

Ibu hamil, bersalin dan nifas yang terkonfirmasi Covid-19 merupakan masalah serius, 
meskipun belum diketahui dampak pengalaman pendemi Covid-19 terhadap kesehatan reproduksi dan mental pada ibu hamil bersalin dan nifas tetapi ada konsesus dihadapkan pada perubahan fisik, psikologis, dan emosional yang besar. Perlunya adanya penelitian kualitatif terkait pengalaman ibu hamil, bersalin dan nifas yang terkonfirmai Covid-19 di Indonesia karena penelitian tersebut dinegara berkembang masih sangat terbatas dan juga untuk mengivestigasi secara mendalam pengalaman ibu hamil bersalin dan nifas yang terkonfirmasi Covid-19 dikarenakan merupakan isu penting untuk strategi promosi, pencegahan dan pemulihan kesehatan yang komperehensif.

\section{Daftar Pustaka}

Amalia, R., Hakimi, M. and Fitriani, H. (2020) 'Evidence-based implementation of normal childbirth: what are the obstacles? (qualitative study)', Journal of Health Technology Assessment in Midwifery, 3(2), pp. 115-126. doi: 10.31101/jhtam.1180.

Barresi, S., Bianchi, S. and Ciriello, E. (2020) 'Vaginal delivery in SARS-CoV-2-infected pregnant women in Northern Italy: a retrospective analysis', 24, pp. 1116-1121. doi: 10.1111/1471-0528.16278.

Bayrampour, H. et al. (2015) 'Effect of depressive and anxiety symptoms during pregnancy on risk of obstetric interventions', 41(7), pp. 1040-1048. doi: 10.1111/jog.12683.

Breslin, N. et al. (2020) 'Coronavirus disease 2019 infection among asymptomatic and symptomatic pregnant women: two weeks of confirmed presentations to an affiliated pair of New York City hospitals', The American Journal of Obstetrics \& Gynecology MFM, 2(2), p. 100118. doi: 10.1016/j.ajogmf.2020.100118.

Brooks, S. K. et al. (2020) 'Since January 2020 Elsevier has created a COVID-19 resource centre with free information in English and Mandarin on the novel coronavirus COVIDresearch that is available on the COVID-19 resource centre - including this for unrestricted research re-use a', (January).
Brown, A. and Shenker, N. (2021) 'Experiences of breastfeeding during COVID - 19: Lessons for future practical and emotional support', (June 2020), pp. 1-15. doi: $10.1111 / \mathrm{mcn} .13088$.

Cao, D., Yin, H., et al. (2020) 'International Journal of Infectious Diseases Clinical analysis of ten pregnant women with COVID-19 in Wuhan, China: A retrospective study', International Journal of Infectious Diseases, 95, pp. 294300. doi: 10.1016/j.ijid.2020.04.047.

Cao, D., Chen, M., et al. (2020) 'Vaginal delivery in women with COVID-19: Report of two cases', BMC Pregnancy and Childbirth, 20(1), pp. 1-6. doi: 10.1186/s12884-020-03281-4.

Chen, H. et al. (2020) 'Clinical characteristics and intrauterine vertical transmission potential of COVID-19 infection in nine pregnant women: a retrospective review of medical records', The Lancet, 395(10226), pp. 809815. doi: 10.1016/S0140-6736(20)30360-3.

Corbett, K. S. et al. (2020) 'SARS-CoV-2 mRNA vaccine design enabled by prototype pathogen preparedness', Nature, 586(October). doi: 10.1038/s41586-0202622-0.

Dashraath, P. et al. (2020) 'Coronavirus disease 2019 (COVID-19) pandemic and pregnancy', American Journal of Obstetrics and Gynecology, 222(6), pp. 521-531. doi: 10.1016/j.ajog.2020.03.021.

Diamond, R. M., Brown, K. S. and Miranda, J. (2020a) 'Impact of COVID - 19 on the Perinatal Period Through a Biopsychosocial Systemic Framework Bio Psycho Social', Contemporary Family Therapy, (0123456789). doi: 10.1007/s10591-02009544-8.

Diamond, R. M., Brown, K. S. and Miranda, J. (2020b) 'Impact of COVID - 19 on the Perinatal Period Through a Biopsychosocial Systemic Framework Bio Psycho Social', Contemporary Family Therapy, (0123456789). doi: 10.1007/s10591-02009544-8.

Dotters-katz, S. K. and Hughes, B. L. (2020) 'Considerations for Obstetric Care during the COVID-19 Pandemic'. 
Dotters-Katz, S. K. and Hughes, B. L. (2020) 'Considerations for Obstetric Care during the COVID-19 Pandemic', American Journal of Perinatology, 37(8), pp. 773-779. doi: 10.1055/s-0040-1710051.

Freitas-Jesus, J. V., Rodrigues, L. and Surita, F. G. (2020) 'The experience of women infected by the COVID-19 during pregnancy in Brazil: A qualitative study protocol', Reproductive Health, 17(1), pp. 1-7. doi: 10.1186/s12978020-00958-z.

González-timoneda, A. et al. (2020) 'Experiences and attitudes of midwives during the birth of a pregnant woman with COVID-19 infection : A qualitative study', Women and Birth, (xxxx). doi: 10.1016/j.wombi.2020.12.001.

Hcini, N. et al. (2021) 'European Journal of Obstetrics \& Gynecology and Reproductive Biology Maternal, fetal and neonatal outcomes of large series of SARS-CoV-2 positive pregnancies in peripartum period: A single-center prospective comparative study', 257, pp. 11-18. doi: 10.1016/j.ejogrb.2020.11.068.

Karavadra, B. et al. (2020) 'Women's perceptions of COVID-19 and their healthcare experiences: A qualitative thematic analysis of a national survey of pregnant women in the United Kingdom', BMC Pregnancy and Childbirth, 20(1), pp. 1-8. doi: 10.1186/s12884-020-03283-2.

Khan, S. et al. (2020) 'Impact of COVID-19 infection on pregnancy outcomes and the risk of maternal-to-neonatal intrapartum transmission of COVID-19 during natural birth', Infection Control and Hospital Epidemiology, 41(6), pp. 748-750. doi: 10.1017/ice.2020.84.

Langlois, J. et al. (2017) 'Association of socioeconomic, school- related and family factors and physical activity and sedentary behaviour among adolescents: multilevel analysis of the PRALIMAP trial inclusion data'. doi: 10.1186/s12889-017-4070-9.

Lim, L. M. et al. (2020) 'Special Report and pregnancy', The American Journal of Obstetrics \& Gynecology, 222(6), pp. 521531. doi: 10.1016/j.ajog.2020.03.021.
Liu, D. et al. (2020) 'Pregnancy and Perinatal Outcomes', (July), pp. 127-132.

Liu, W. et al. (2020) 'Clinical characteristics of 19 neonates born to mothers with'.

Mahajan, N. N. et al. (2020) 'Preparedness , administrative challenges for establishing obstetric services, and experience of delivering over 400 women at a tertiary care COVID - 19 hospital in India', (September), pp. 188-196. doi: 10.1002/ijgo.13338.

Masjoudi, M. et al. (2020) 'Explaining the experience of prenatal care and investigating the association between psychological factors with self-care in pregnant women during COVID-19 pandemic : a mixed method study protocol', pp. 1-7.

Mcdonnell, S. et al. (2020) 'European Journal of Obstetrics \& Gynecology and Reproductive Biology The impact of the Covid-19 pandemic on maternity services: A review of maternal and neonatal outcomes before, during and after the pandemic', 255, pp. 172-176. doi: 10.1016/j.ejogrb.2020.10.023.

Mizrak, B. and Nur, E. (2020) 'The experiences of pregnant women during the COVID-19 pandemic in Turkey: A qualitative study', Women and Birth, (December 2019). doi: 10.1016/j.wombi.2020.09.022.

Peng, S. et al. (2020) 'The Lancet Regional Health Western Pacific A study of breastfeeding practices, SARS-CoV-2 and its antibodies in the breast milk of mothers confirmed with COVID-19', $4 . \quad$ doi: 10.1016/j.lanwpc.2020.100045.

POGI (2020) 'No Title'.

Rasmussen, Sonja A et al. (2020) 'Coronavirus Disease 2019 ( COVID-19) and', (January).

Rasmussen, Sonja A. et al. (2020) 'Coronavirus Disease 2019 (COVID-19) and pregnancy: what obstetricians need to know', American Journal of Obstetrics and Gynecology, 222(5), pp. 415-426. doi: 10.1016/j.ajog.2020.02.017.

Ri, K. K. (2020) 'Pedoman bagi ibu hamil, bersalin, nifas, dan bayi baru lahir'. 
Sheng, W. H. (2020) 'Coronavirus disease 2019 (Covid-19)', Journal of Internal Medicine of Taiwan, 31(2), pp. 61-66. doi: 10.6314/JIMT.202004_31(2).01.

'Since January 2020 Elsevier has created a COVID19 resource centre with free information in English and Mandarin on the novel coronavirus COVID- 19 . The COVID-19 resource centre is hosted on Elsevier Connect, the company' s public news and information' (2020), (January).

Slade, T., Johnston, A. and Browne, M. A. O. (2009) '2007 National Survey of Mental Health and Wellbeing : methods and key findings'.

Soma-pillay, P. et al. (2016) 'Physiological changes in pregnancy', 27(2), pp. 89-94. doi: 10.5830/CVJA-2016-021.

Thayer, Z. M. and Theresa E. Gildner (2020) 'Birth plan alterations among American women in response to', (April), pp. 969-971. doi: 10.1111/hex.13077.
Topalidou, A. and Thomson, G. (2020) 'Covid-19 and maternal and infant health: Are we getting the balance right? A rapid scoping review', pp. 1-16.

'Universal testing for severe acute respiratory syndrome' (2020), (January).

Wu, Y. (2020) 'Coronavirus disease 2019 among pregnant Chinese women : case series data on the safety of vaginal birth and breastfeeding', pp. 1109-1115. doi: 10.1111/1471-0528.16276.

Zhao, Y. et al. (2020) 'Evaluation and design of public health information management system for primary health care units based on medical and health information', Journal of Infection and Public Health, 13(4), pp. 491-496. doi: 10.1016/j.jiph.2019.11.004.

Zhu, N. et al. (2020) 'A Novel Coronavirus from Patients with Pneumonia in China, 2019', New England Journal of Medicine, 382(8), pp. 727-733. doi: 10.1056/nejmoa200101 